\title{
Central and Eastern European Accession: Changing Perspectives on Migrant Workers
}

\author{
Ian Fitzgerald* and Rafal Smoczyński** \\ *Northumbria University \\ E-mail: lan.fitzgerald@northumbria.ac.uk \\ **Institute of Philosophy and Sociology of the Polish Academy of Sciences \\ E-mail: rsmoczyn@ifispan.waw.pl
}

This article provides a reflection on the period since the May 2004 Central and Eastern European (CEE) accession and subsequent migration to the UK, and on shifting perspectives of and towards CEE migrants in this period. The authors have been researching this phenomenon in the North of England since 2005 through a series of studies as well as ongoing engagement with regional respondents. CEE migration is analysed through the perspectives of government, employers and trade union interests. A central argument is that attitudes to CEE migrants changed following the 2008 financial crisis as funding for local authorities was reduced, obscuring evidence-based arguments for their value to the UK labour market.

Keywords: Communities, government, migrant workers, trade unions.

\section{Introduction}

Although the UK Supreme Court has clarified parliament's role with regard to Article 50, signalling the beginning of the UK's formal withdrawal from the European Union, we will not know what this actually means for freedom of movement and the UK economy for some time. However, what we do know is that Central and Eastern European (CEE) workers are likely to face significant changes in the labour market. Given this, we intend to reflect on the entry of these workers, and in particular Polish workers, to the north of England since 2005. This draws on a number of studies carried out during this period, as well as ongoing engagement with the Polish community in the north east, the north east regional development agency, One North East, and trade unions. ${ }^{1}$

Did attitudes towards migrant workers shift significantly in the run-up to the Brexit vote? This is an important question and reminds us that it was not Brexit alone that caused hostility to migrants but that there was a long-standing - and indeed growing antipathy to migrant workers, which was intertwined with more wide-ranging hostility to migration and particular ethnic groups of migrants. ${ }^{2}$ One way to understand this path is by reflecting back on the perspectives of the state, the employers and trade unions. Although interconnected, each of these have engaged in distinctive ways with the migration process.

\section{The roots of the Brexit vote? The UK's response to the accession}

The role of the state

The UK government in May 2004 was one of only three EU member states that did not introduce transitional measures for CEE populations (A8 workers). ${ }^{3}$ The belief was 
that not many CEE migrants would come to the UK; however, Salt and Millar (2006) soon confirmed that this was undoubtedly the largest ever single in-migration to the UK. To seek to understand this inflow, government initiated both a series of geographic assessments of local areas (e.g. Northumberland County Council, 2006; Zaronaite and Tirzite, 2006; Carlisle City Council, 2008) and a number of regional and national impact evaluations (McKay and Winklemann-Gleed, 2005; LSC, 2007; Experian, 2008; TNS, 2008). These assessments mapped migrant populations and identified a number of key issues, such as the concentration of migrants in certain industrial sectors, high levels of exploitation (such as low wages and poor conditions) and the limited negative impacts that migrants had on wages and job availability in local labour markets. It was also clear that new migrants were now working in areas where levels of migration had previously been low.

In response to growing pressure on the government from local authorities, due to increased demands on local services, a series of good practice guides for local councils dealing with the accession migration were published (e.g. CRC, 2007; I\&DEA, 2007). The northern Regional Development Agencies focused much of their work on developing responses based on the Scottish Fresh Talent initiative ${ }^{4}$ - complementing the government's evolving points-based system (Experian, 2006). Our research contributed to this with several analyses of the Worker Registration Scheme data produced for One North East (see Fitzgerald, 2007a, 2008), which included identification of migrant skill levels. There were also government-initiated labour market investigations, including studies commissioned by the Department for Work and Pensions (Portes and French, 2005; Gilpin et al., 2006) and the Home Office (Dench et al., 2006).

A number of councils also provided 'welcome' packs for new CEE migrants either in hard copy format or via the Internet. These were likely to be local council, police or other government agency initiated. Alongside these were a range of service providers invited to set-up stalls in a local community centre. Service providers included banks, the Construction Industry Training Board, solicitors and trade unions. Several agencies also operated telephone helplines, some catering for non-English speakers. ESOL (English for Speakers of Other Languages) was recognised as a high priority but overall provision was piecemeal, and reliant on either medium-term or intermittent funding. The Polish community, though, also supported each other and perhaps one of the most tangible manifestations of this was the increased growth of Polish language and administered websites. In 2007, with the help of a Polish community activist, we estimated that there were around thirty-five of these either related to countries (UK, Scotland and Wales) or specific towns and cities (Bobrzak and Fitzgerald, 2007). The ones for Hull, Manchester, Leeds and Newcastle still exist today and provide active ongoing user news, debate and national EU, Polish and UK news. Another significant co-ethnic response was the growth of entrepreneurial activity, with the development of new Polish businesses in the regional economy (Woodford et al., 2007). Garapich (2008) also noted nationally a developing world of Polish business activity.

It is also important to note that welcome packs were in part an attempt to address rumours and tensions in local communities between either resident white populations who had not hitherto experienced significant in-migration and/or, albeit much more rarely, resident BME communities. However, these tensions were rarely directly identified (see Carby-Hall, 2007, for an exception) or were overshadowed by wider discourses. 
The perspectives and role of employers

Portes and French (2005) reported broadly positive views from employers on the contribution of CEE workers. Although stating it was too early to draw any firm conclusions, the authors did note evidence from the agricultural and fishing sectors of brakes on wage rises. However, Gilpin et al. (2006) found little overall impact on both wages or of the displacement of indigenous workers.

Employers have tended to view Polish and other CEE workers as strategically important for competitive success. In fact, at a relatively early stage the Chartered Institute of Personnel and Development (CIPD, 2005, 2006) reported that 25 per cent of their employer respondents were actively seeking foreign workers, including those from CEE countries. These reports had a similar theme of migrants filling vacancies, with employers rejecting the 'core jobless', underpinned by broad statements that, for example, migrant workers had a 'positive work ethic'. Others also identified the significance of recruitment agencies for the supply of Polish and other CEE workers (see Ward et al., 2005; Currie, 2006; USDAW, 2006).

Dench et al. (2006) echoed the CIPD theme and highlighted what has now become the leitmotif of Polish workers - a 'good' attitude and work ethic. They also noted that in terms of their productivity and speed, employers stated that these migrants were prepared to work harder, longer and more flexibly than indigenous workers. However, MacKenzie and Forde (2009) criticised the stereotyping of such attitudes, highlighting how the 'good' worker was often associated with minimal terms and conditions, that is high levels of exploitation. Whilst investigating how Poles were obtaining employment in the north east and north west food processing ${ }^{5}$ and construction sectors, we identified this phenomenon (Fitzgerald, 2007b). Here we found that when trade unions or inspectorates tried to intervene to alleviate issues of exploitation, employers tended to respond by moving migrant workers to other sites, exchanging them for other groups.

This was a more shadowy side to the employer use of migrant and Polish workers, one absent from government labour market assessments. For example, in the north east construction sector, we found that Polish workers were initially (in Poland) shown Polish language 'contracts of employment' (contract of service in English law) then in the UK asked to sign an English language 'contract for service' (self-employed status in English law) (Fitzgerald, 2006). This contract for service meant that many Polish workers were not eligible for holidays or national insurance payments by the employer. Another deception was to pay a cheque to one Polish worker from a team of other workers (the others did not have bank accounts); in law, he then became the subcontractor and took on all employer responsibilities. Worse still, Polish workers were not paid either the correct rate for the job or indeed their wages, instead falling victim to employer violence when they voiced protest. Other complaints were delays in payment, lack of transparency in terms of what was being deducted from their pay and dismissal without pay or notice. As a Polish worker at the time stated:

Company X doesn't pay for the work done; when they pay, the rates are very low ... There are no pay slips but we are told tax is deducted at 23 per cent every week. In Poland we agreed to work for $£ 9$ per hour, the first pay is after one month but only two weeks was paid. We [did] ask the union to investigate the matter ... to stop the exploitation of the Polish. [But] one day we were sacked with no notice and no pay ... When I arrived in the country I had no money so had to take up position ... to earn money to live. 
This of course was not limited to only one company and many others have identified that Polish and other migrants have experienced poor conditions of employment (Craig et al., 2007; Wills et al., 2010); poor or no housing (McKay and Winklemann-Gleed, 2005; Carby-Hall, 2007); and an increased risk of significant injury or death their new workplaces (CCA, 2009) when entering the UK's increasingly deregulated market economy.

\section{The role of trades unions}

It is clear that as well as facing the actual practicalities of entering a new country and locality, these migrants were coping with difficult situations at work, many of which constituted exploitation. It is thus instructive to consider the role of trades unions. The Trade Union Congress (TUC) commissioned a number of studies in this area. Initially, these focused on examining the wider impacts on local communities of employing migrant workers. The TUC (2007: 3) explicitly recognised local difficulties in its Economics of Migration: Managing the Impacts, posing such questions as 'Has migration led to unemployment?' and 'Has migration driven down wages?'. In the 2006 TUCcommissioned north east construction study discussed earlier, there were initially reports of anti-Polish sentiments and comments on sites from indigenous workers. However, it was stated by respondents that when Polish workers began working on these sites, and their exploitation was witnessed by indigenous workers, concerns were soon expressed about what trades unions were doing to address this exploitation. Our early work only briefly considered this xenophobia but found little tension, instead focusing on the plight of many new CEE migrant workers.

The four TUC projects in the north of England overall highlighted generally inclusive indigenous workers and trade unions seeking to engage with new Polish workers, as well as identifying the exploitation of these workers. ${ }^{6}$ An ESRC national project (undertaken with Jane Hardy) on the response of UK trade unions to the Polish migration also identified inclusive and innovative UK national trade unions (Hardy, 2007). The GMB trade union for example, opened three Polish-migrant holding branches to ease Poles into more established branches. The 2008 study for the Yorkshire and the Humber TUC investigated the information needs of new Polish migrants. This identified information sources such as the TUC Working Smart website with information on employment rights and EU-based information sources. Trade Unions also attempted to support migrants through drop-in centres or sessions, identified earlier. An example here are the GMB trade union who ran a series of drop-in sessions as part of their then 'Reaching Out to New Communities' project.

\section{The economic crisis as a driver for change?}

In the previous section, it was argued that there were some negative responses to CEE migration but an analysis of evidence from our three perspectives demonstrates a largely positive UK response. The Home Office (2007), although giving an overall guarded response to the migration, provides a useful summary of much of the positive immigration literature, indicating that the fiscal and economic impacts of migration were largely benign or positive. However, the period from 2008 onwards saw a change and these negative strands have now developed into a full-scale crisis for multicultural Britain. One of the 
strands not mentioned yet and providing an important context was the response of the UK media. ${ }^{7}$ Certain newspapers such as the Daily Mail, whilst reporting on the poor conditions that new Polish workers suffered also frequently had negative headlines. For example 'East Europeans' are failing to integrate into British society' (09/06/2006), 'Poles claiming UK benefit for children they left back home' (13/08/2006) and 'Flood of migrants puts pressure on services' (26/10/2006). We and others (Mawby and Gisby, 2009; Spigelman, 2013) have argued that this developed into what can be understood as a 'moral panic' (Cohen, 1972), with UKIP and a resurgent Conservative party now embracing the antiimmigration debate. CEE migrants were often subjected to 'manufactured' news and in 2008 the Federation of Poles in Great Britain contacted the Press Complaints Commission about the Daily Mail slandering of UK Poles (Brook, 2008). Nevertheless, the discursive strategies of the mass media continued to portray migration in a negative manner, with the public systematically fed stereotypical and hostile headlines.

Analysing again our key perspectives of migration, we return to that of government and Parliament. One early indicator of a change in direction is evidenced by the House of Lords The Economic Impact of Immigration inquiry (2008). Its conclusions were on the whole negative regarding the benefits of immigration, with the report noting that while certain employers gained from immigration, the country as a whole did not, with many low-paid and young indigenous workers 'losing out'. Strangely, this was not the precursor to a succession of new government impact assessments and evaluations but in fact fewer such reports. Its influence though was overshadowed by a more pressing issue, namely the withdrawal of funding for such local and regional investigations coupled with cuts to the quality and quantity of initiatives discussed above. The reason for this 'parking' of the issue was not that CEE migration was no longer important but that it was dwarfed by the crisis in the banking sector. ${ }^{8}$ Interestingly in 2010, the government's 'Migration Impact Fund', introduced in 2008 to assist with easing tensions in local communities (to be used by local councils, the police, primary care trusts and voluntary bodies), was withdrawn by the newly appointed Eric Pickles as 'in light of the overall fiscal position the government concluded that it was not a priority funding stream' (Wintour, 2010). This very much summarised the new government stance on migration: Wintour noted that this was 'scrapped by stealth' alongside government public statements that the UK would reduce its net migration to tens of thousands each year.

The position of employers was now increasingly characterised by a 'race to the bottom' in terms of wages and conditions (Waite et al., 2016), particularly for more precarious workers, whether UK nationals or CEE workers. Whilst employer groups such as the $\mathrm{CBI}$ and the Federation of Small Businesses, amongst others, made it clear that migrants were still vital particularly for certain low-skilled industries, ${ }^{9}$ trade unions found it more difficult to commit resources to migrant workers, as membership levels began to fall due to growing redundancies and wages reductions (see BIS, 2016). An example of what this meant for Polish workers was in the north east where campaigns were scaled back if they did not gain a significant number of members. Resources were instead moved to other plants where either there was a pre-existing membership or large numbers of workers had joined the union.

Thus, prior to the Referendum the overall situation became more difficult for large numbers of migrant workers. For example with new Polish communities, a questionnaire (125 respondents) and a series of fifty in-depth interviews in the north of England identified that Polish workers, who had not experienced exploitation and ill-treatment before were 
now suffering (Fitzgerald and Smoczyński, 2015). Respondents said that now it was not uncommon to be insulted in the community, on public transport and at work. Exclusionary behaviour and racial harassment in the workplace was now a significant issue, as evidenced by these extracts from four Polish respondents:

in the company British make you feel that being a Pole means that you are worse than them.

on my locker there was a writing saying lazy Polish $b^{*} t^{*}$ rds get the $f^{* *} k$ out of here, go back to Poland.

there were women in the former company who talked about Poles more or less like that 'lazy Polish b*tch, stupid Poles'.

colleagues from the company several times spoke openly that members of their families do not have jobs because the Poles took their posts.

In fact, only one respondent identified employer support to deal with these issues, with respondents stating that this had become worse since the financial crisis as people lost their jobs, wages were reduced or frozen and many suffered in other ways. As we know historically, immigrants have always been an easy target to blame. However, of those who suffered exploitation and ill-treatment, over two-thirds believed their economic situation to be either 'good' or 'correct', and it can be argued that to some degree they had assimilated elements of the dominant discourse about them.

\section{Conclusion: Brexit a return to the 1960s?}

We have argued that following the accession of A8 workers there was pressure on some local communities and exploitation of migrant workers, with some industries using these workers to reduce wages for all. However, entering 2008 there was an overall positive narrative with regard to CEE migration. Since then though, there has not only been a rise in racist and discriminatory behaviour (as stated by some of our Polish respondents and other commentators), reminiscent of the 1960s, but also an accompanying increasingly dominant and hostile political narrative and the rise of 'legitimate' anti-immigration parties such as UKIP. This misleading political and media comment underscores distasteful kneejerk reactions to immigration and feeds into populist myths such that it seems the UK has forgotten its multiracial roots, shameful past discrimination and moves towards a more inclusive society. Therefore, if we must now provide positive arguments for migration to this country so be it.

Aside from Polish and other immigrants often doing the jobs that indigenous workers do not want and providing an invaluable source of young blood whilst the UK ages, there are sound monetary, housing and medical reasons that support the case for immigration. For example, Dustmann and Frattini (2014) recently calculated that between 2001 and 2011 the net annual fiscal contribution of CEE workers was $£ 4.9$ billion; of other Europeans it was $£ 15.3$ billion; and of those from outside Europe (predominantly asylum-seekers and refugees) $£ 5.2$ billion. In relation to claims that migrants have 'stolen our houses', VargasSilva (2016) found that the foreign-born population were not only less likely to own a home than the UK-born population but that they were also almost three times as likely to be in the 
private rental sector and not social housing. Perry (2012) found that immigrants residing in privately rented housing were often living in poor and exploitative conditions. Finally, Giutella et al. (2015) have recently investigated the effects of immigration on access to health care in England. They found 'no evidence of significant effects on waiting times in A\&E and elective care' (2015: 4) and indeed showed that an increase in immigrants in a locality can lead to a reduction in outpatient waiting times, whilst Cook et al. (2012) observed that many of their northern CEE respondents returned home for all types of medical treatment rather than seeking help in the UK and this was also reported to us by a number of our respondents (Fitzgerald and Smoczyński, 2015).

At the time of writing, the outcome of the Brexit negotiations, which have just been given parliamentary approval to proceed, are far from clear. What is clear is that no-one has honestly addressed the issue of where the labour will be found to replace the migrant workers who have largely undertaken the dangerous, dirty and difficult jobs in the UK labour market for many past years but who seem likely, in present political debates, to be unable to do so. This is a challenge facing all those concerned with the future shape of the UK labour market as a whole and the conditions of those working within it, particularly in its most precarious segments.

\section{Notes}

1 This led to a Ref 2014 impact case study 'The Impact of Polish migrant worker research on policy and practice', impact.ref.ac.uk/CaseStudies/CaseStudy.aspx?ld=35155.

2 While this article focuses on CEE migrants, the growth of asylum-seeking and the typically misleading links made by the media with Islamic terrorism have been significant recent factors in driving migrant hostility: see http://www.irr.org.uk/news/racial-violence-and-the-brexit-state/

3 A Worker Registration Scheme (WRS) was introduced only for employed accession workers who had to stay registered for one-year. There were also some limitations on state benefits but the WRS was abandoned in 2011.

4 A government initiative encouraging people to settle in Scotland: see http://www.gov.scot/ resource/doc/235857/0064664.pdf

5 As had researchers elsewhere: see e.g. Scott et al. (2012), which identified forced labour in the food industry.

6 As well as the projects noted, there were also Fitzgerald (2005) Migrant Workers in the North East of England, Northern Trades Union Congress; Fitzgerald (2008) Moving Target: The informational needs of Polish migrant workers in Yorkshire and the Humber, Trades Union Congress. This research also identified a number of positive employer responses and it was clear that some did not just see Polish and other migrants as a way of cutting costs but as hard working and reliable.

7 We have looked at this in Smoczyński et al. (2013)

8 The National Audit Office states that the total peak support made available to banks was $£ 1,162$ billion of which $£ 85$ billion is still outstanding. (http://www.nao.org.uk/highlights/taxpayersupport-for-uk-banks-faqs/\#) This prompted significant reductions in central government funding to local authorities. For example between 2009-10 and 2014-15 local authority spending was reduced by 20 per cent (Innes and Tetlow, 2015 - see also LGA, 2014; Hastings et al., 2015, for further details).

9 See recent statements from the CBI following Brexit, for example Press Association (2016).

\section{References}

Business, Innovation and Skills (BIS) (2016) Trade Union Membership 2015: Statistical Bulletin, London:

Department for Business, Innovation and Skills. 
Bobrzak, K. and Fitzgerald, I. (2007) Polish Language, Polish Administered Community Websites, Northumbria University Mapping Project.

Brook, S. (2008) 'Polish Federation accuses Daily Mail of defamation', The Guardian, 15 March.

Carby-Hall, J. (2007) The Treatment of Polish and Other A8 Economic Migrants in the European Union Member States, Report for the Commissioner for Civil Rights Protection of the Republic of Poland.

Carlisle City Council (2008) Migrant Workers: A Report of the Task and Finish Group, Carlisle: Carlisle City Council May.

Centre for Corporate Responsibility (CCA) (2009) Migrants' Workplace Deaths in Britain, Report in association with Irwin Mitchell, March, London.

Chartered Institute of Personnel and Development (CIPD) (2005) Recruitment, Retention and Turnover, Annual Survey Report, London: Chartered Institute of Personnel and Development.

Chartered Institute of Personnel and Development (CIPD) (2006) Recruitment, Retention and Turnover, Annual Survey Report, London: Chartered Institute of Personnel and Development.

Cohen, S. (1972) Folk Devils and Moral Panics, London: McGibbon \& Kee.

Cook, J., Dwyer, P. and Waite, L. (2012) 'Accession 8 migration and the proactive and defensive engagement of social citizenship', Journal of Social Policy, 41, 2, 329-47.

Craig, G., Gaus, A., Wilkinson, M., Skrivankova, K. and McQuade, A. (2007) Contemporary Slavery in the UK: Overview and Key Issues, York: Joseph Rowntree Foundation.

Commission for Rural Communities (CRC) (2007) A8 Migrant Workers in Rural Areas, Briefing Paper, Cheltenham: Commission for Rural Communities.

Currie, S. (2006) The Role Played by Agencies and Employers in Facilitating Post-Accession Polish Migration to the UK, COMPAS International Conference International Labour Migration: In Whose Interests? University of Oxford, 5-6 July.

Dench, S., Hurstfield, J., Hill, D. and Akroyd, K. (2006) Employers' Use of Migrant Labour, Home Office Online Report 04/06, London: Home Office.

Dustmann, C. and Frattini, T. (2014) 'The fiscal effects of immigration to the UK', The Economic Journal, 124, 593-643.

Experian (2006) Attracting Talent: The Impact of Migrant Workers on the Cheshire and Warrington Labour Market, Report for North West Development Agency.

Experian (2008) Demography, Migration and Diversity in the Northwest, Report for North West Development Agency.

Fitzgerald, I. (2006) Organising Migrant Workers in Construction: Experience from the North East of England, Northern Trades Union Congress.

Fitzgerald, I. (2007a) An Analysis of the North East Worker Registration Scheme Data, Talent North East steering group, One North East.

Fitzgerald, I. (2007b) Working in the UK: Polish Migrant Worker Routes into Employment, Northern Trades Union Congress.

Fitzgerald, I. (2008) An Analysis of the North East Worker Registration Scheme Data: Second Briefing Paper, Talent North East steering group, One North East.

Fitzgerald, I. and Smoczyński, R. (2015) Integration of Polish Workers in the North, Joint Northumbria University and Polish Academy of Sciences Project.

Garapich, M. (2008) 'The migration industry and civil society: polish immigrants in the United Kingdom before and after EU Enlargement', Journal of Ethnic and Migration Studies, 34, 5, 73552.

Gilpin, N., Henty, M., Lemos, S., Portes, J. and Bullen, C. (2006) The Impact of Free Movement of Workers from Central and Eastern Europe on the UK Labour Market, London: Department for Work and Pensions, Working Paper No 29.

Giutella, O., Nicodemo, C. and Vargas-Silva, C. (2015) The Effects of Immigration on NHS Waiting Times, Working Paper 124, Oxford: Compas, University of Oxford.

Hardy, J. (2007) Cross Border Trade Union Collaboration and Polish Migrant Workers in Britain, ESRC Grant Award number RES-000-22-2034, Economic and Social Research Council. 
Hastings, A., Bailey, N., Bramley, G., Gannon, M. and Watkins, D. (2015) The Cost of the Cuts: The Impact on Local Government and Poorer Communities, York: Joseph Rowntree Foundation.

Home Office (2007) The Economic and Fiscal Impact of Immigration, a Cross-Departmental submission to the House of Lords Select Committee on Economic Affairs, October, London: Home Office.

House of Lords (2008) The Economic Impact of Immigration, London: House of Lords.

I\&DEA (2007) New European Migration: Good Practice Guide for Local Authorities, Communities and Local Government and Institute of Community Cohesion, London: I\&EA, June.

Innes, D. and Tetlow, G. (2015) Central Cuts, Local Decision-Making: Changes in Local Government Spending and Revenues in England, 2009-10 to 2014-15, Institute for Fiscal Studies Briefing Note BN166.

Local Government Association (LGA) (2014) Under Pressure: How Councils are Planning for Future Cuts, April, Local Government Association.

Learning and Skills Council (LSC) (2007) Migrant Workers and the Labour Market: Review of LSC research on Labour Market Participation, Skills and Skills Provision for Migrant Workers, January, London: Learning and Skills Council.

MacKenzie, R. and Forde, C. (2009) 'The rhetoric of the "good worker" versus the realities of employers' use and the experiences of migrant workers', Work, Employment and Society, 23, 1, 142-59.

Mawby, R. and Gisby, W. (2009) 'Crime, media and moral panic in an expanding European Union', The Howard Journal, 48, 1, 37-51.

McKay, S. and Winklemann-Gleed, A. (2005) Migrant Workers in the East of England, Report for the East of England Development Agency.

Northumberland County Council (2006) International Migrant Workers in Northumberland, Northumberland County Council.

Perry, J. (2012) UK Migrants and the Private Rented Sector: A Policy and Practice Report from the Housing and Migration Network, York: Joseph Rowntree Foundation.

Portes, J. and French, S. (2005) The Impact of the Free Movement of Workers from Central and Eastern Europe on the UK Labour Market: Early Evidence, Department for Work and Pensions Working Paper 18.

Press Association (2016) 'Hard Brexit risks destroying UK's open economy, says CBI chief', The Guardian, 10 October.

Salt, J. and Millar, J. (2006) 'Foreign labour in the United Kingdom: current patterns and trends', Labour Market Trends, Titchfield: Office for National Statistics, 114, 10, 335-55.

Scott, S., Craig, G. and Geddes, A. (2012) The Experience of Forced Labour, York: Joseph Rowntree Foundation.

Smoczyński, R., Chan, P. and Fitzgerald, I. (2013) Societal Reactions toward Polish Economic Migrants in Northern England after 2004, Polish National Science Centre award.

Spigelman, A. (2013) 'The depiction of Polish migrants in the United Kingdom by the British press after Poland's accession to the European Union', International Journal of Sociology and Social Policy, 33, $1 / 2,98-113$.

TNS (2008) Migration and Social Housing Survey, Report for the Local Government Association, London. Trade Union Congress (TUC) (2007) The Economics of Migration: Managing the Impacts, June, London: Trade Union Congress.

Union of Shop, Distributive ND Allied Workers (USDAW) (2006) Agency and Migrant Workers, Executive Council Statement to the 2006 ADM.

Vargas-Silva, C. (2016) Migrants and Housing in the UK: Experiences and Impacts, Briefing of 28 October 2016, Oxford: Compas, University of Oxford.

Waite, L., Craig, G., Lewis, H. and Skrivankova, K. (2016) Vulnerability, Exploitation and Migration, London: Palgrave.

Ward, K., Coe, N. M. and Johns, J. (2005) The Role of Temporary Staffing Agencies in Facilitating Labour Mobility in Central and Eastern Europe, Manchester: University of Manchester. 
Wills, J., Datta, K., Evans, Y., Herbert, J., May, J. and Mcllwaine, C. (2010) Global Cities at Work: New Migrant Divisions of Labour, London: Pluto Press.

Wintour, P. (2010) 'Fund to ease impact of immigration scrapped by stealth', The Guardian, 6 August.

Woodford, G., Langdon, K., Richardson, P. and Fitzgerald, I. (2007) Enterprise for BME Communities, Refugees and Migrants, ONE NorthEast.

Zaronaite, D. and Tirzite, A. (2006) The Dynamics of Migrant Labour in South Lincolnshire, Report for the East Midland Development Agency and Lincolnshire Enterprise. 